\title{
Combination of Ideological and Political Education in Business Major with Work-integrated Learning in Vocational Education
}

\author{
Li-li Liu, Yan-hua Su and Qian Xia \\ Qinhuangdao Institute of Technology, Qinhuangdao, Hebei, China \\ yammm2013@126.com
}

\begin{abstract}
At present, the pushing-on talents-training mode of work-integrated learning requires higher expectation in the ideological and political education for commerce specialty in higher vocational colleges. According to the characteristics of talentstraining mode of the work-integrated learning and the characteristics of business personnel, the ideological and political education should keep pace with the times to innovate educational ideas in order to explore new approaches of ideological and political education which is guided by profession, carried by enterprise culture. Thus, classroom teaching is extended and expanded; new approaches of ideological and political education are constructed and implemented by college and enterprise.
\end{abstract}

Index Terms - work-integrated learning; commerce specialty at polytechnics; ideological and political education; innovation

\section{Introduction}

National Medium and Long-term Educational Reform and Development Plan (20102020 years) proposed to vigorously develop the occupation education, and required to develope mode of work study combination, school enterprise cooperation and post talent engineering practice, so as to improve the quality as the key. Mode of work study combination continuously push forward higher requirements to the ideological and political education of professional higher business combination. Therefore, the work of ideological and political education of professional higher business must keep pace with the times, according to the "talent cultivation mode characteristics and business personnel combination" characteristics, explore with "the new way of Ideological and political education specialty of higher business personnel training.

\section{The Main Task of Ideological and Political Education of Higher Business Professionals}

"College Students" ideological and political education is the fundamental task to Marx the Lenin doctrine, Mao Zedong thought, Deng Xiaoping theory, the important thought of 'Three Represents' and Scientific Outlook on Development as guidance, comprehensively implement the party's education policy, training of qualified builders and reliable successors Dezhitimei all-round development of socialist." Higher business students requires not only the good professional ability, but also need the noble moral, good psychological quality and social ability. This also makes higher business major of Ideological and political education take more mission.
A. Carrying out the Education of Ideal and Faith in Close Contact with the Social and Economic Activities

Ideal and belief is an important part of people's spiritual world. The ideal and belief education and ideological and political education have a high degree of internal consistency. At present, the rapid development of economic globalization, the multicultural coexisting, the East West cultural exchange and collision of different ideology, constantly confrontation and struggle, profound changes have taken place in people's spiritual life and ideas. Commerce industry contacts is a complex population, vulnerable to different cultures. If not there is not strong ideal and faith, people are easily to get lost and lack the position.

Therefore, the ideological and political education of higher business must adhere to the guiding position of Marxism in China, Marx ideology, the Marx doctrine of ideal and belief education closely with social economic activities associated with the embodiment of Marx's ideology, guiding function on social economic development.

\section{B. In the Development of Multi Compound Talents for the Purpose of Enhancing Students' Quality}

Trade industry competition is unusually intense, so business students not only have to cope with the changing international situation, but also clearify the domestic and international relevant policies and regulations, and be familiar with the business processes, etiquette and so on. Therefore, higher business majors must be multivariate compound talents. They will have to be honest and trustworthy as the core of the ideological and moral quality, with strong will as the core of the psychological quality, skilled in communication skills as the core of the social ability and flexibility and decisive decision-making ability. This requires higher business major of Ideological and political education to expand the content according to the needs, social development and students' growth, and to strengthen the socialist democracy and the legal system of education, education, humanistic quality and scientific spirit of collectivism and team spirit education, so as to improve the overall quality of the individual.

\section{Carry out Ideological and Political Education with the} Purpose of cultivating Students' Consciousness

In today's society, business opportunities are everywhere, but what people lack are eyes able to find business opportunities. Therefore, the ideological and political 
education of higher business should inspire students' enthusiasm of free exploration, encourage the student to individually develop, improve students' comprehensive subject consciousness and innovation ability, and cultivate students' ability to discover and seize market opportunities. "The training goal of Ideological and political education is to adhere to a comprehensive concept of development, promote the comprehensive development of human freedom." In the process of teaching, to establish a democratic and equal, harmonious relationship between teachers and students, to teach students in accordance with their aptitude, combining students' physical and mental development characteristics and interests, encourage students to take the initiative to explore the unknown, enhance psychological adjustment ability, social ability to adapt to the students and social ability, stimulate the students' autonomy in learning, so that the subjectivity can get the maximum limit display.

\section{The Requirement of Work-integrated Learning in Vocational Education to Ideological and Political Education in Business Major}

Work-integrated Learning mode is the school and enterprise practice together in the mode of education. It takes the occupation as orientation, schools, enterprises, students as the subject of education, make full use of educational environment and teaching resources of schools and enterprises, and combine the school classroom teaching and the practice of organic, so that it can combine teaching with practice. The "combination" mode, higher business majors and internship alternately, this teaching mode put forward higher request to the business vocational college ideological and political education.

\section{A. Diversifing the Teaching Subjuct}

The development of talents training path require multiagent cooperation. In the "combination" environment, higher business professional in addition to accept the classroom teaching, almost half of the time to practice in enterprises practice. In order not to make the internship phase of the disjunction of Ideological and political education, ideological and political education must reform mode of higher business professional, let the school, enterprises become the double main body of Ideological and political education of the students. On the one hand, the school to carry out ideological and Political Theory Course Teaching in schools, on the other hand, enterprises to provide training places for students to carry out ideological and political education, by its corporate culture, staff code, occupation moral requirement, enterprise management personnel, technical experts, labor model, excellent staff and so can be used as teaching people. Schools and enterprises to carry out ideological and political education work along both lines, more conducive to improving student identity on the content of education, and improve students' occupation accomplishment.

\section{B. The Reality of Teaching Content}

The traditional environment of Ideological and political education of college students is relatively closed and single.
The higher business majors activity space is extended from the classroom to the enterprise and social combination. The students out of the ivory tower to the real society, contact. Some bad behaviors existed in the society and some companies, enterprises one-sided profit behavior, will bring certain impact on the thinking to the students, the selection and influence their behavior. Therefore, the contents of Ideological and political education of professional higher business to life, reality, in teaching and practice to tell the students a relatively real society, guide them to rational, dialectical view of social status, to achieve perfect ideological moral quality in work and life.

\section{Flexibility of Teaching Management}

In the "Combination" training mode, student internships is dispersed in various practice companies or the same company in different jobs. Because of their work and study time interleaving, dispersed locations, the complexity of the situation, if want to unify to carry out ideological and political education is difficult. Therefore, higher business professional to ideological and political education into the daily management, teachers, management personnel, practice unit related guidance personnel into education system, with a common, form resultant force. At the same time also need to play the subjectivity of students, improve the enthusiasm and initiative of the self management and self education.

\section{Diversity of Teaching Methods}

Most of the traditional methods of ideological political education to instill the main classroom. "Combination" training mode, students can participate directly in the line of production, operation and management work, teaching environment more complex, higher teaching difficulty. This requires that the ideological and political education of higher business to be innovative ways, through counseling education, typical education, encourage education, psychological counseling and crisis management methods will require the ideological and political theory education into method in theory, and then into the self of students' moral character.

\section{Reform and Innovation of Ideological and Political Education in Business Major under the Mode of Work-Integrated Learning}

\section{A. Basic Principles}

In the combination training mode, the ideological and political education of higher business reform and innovation should follow the following principles:

1) Close to the occupation, and prominent practice. Wokr-integrated learning expands the scope of the ideological and political education curriculum resources in professional higher business combining work with study", also increased the difficulty of the ideological and political education. Therefore, higher vocational business specialty in Ideological and political education should be closer to the occupation, the prominent practice, not only to explain the theoretical knowledge, but also the occupation, position the theory knowledge and the students closer together; we should not only strengthen the classroom teaching, but also promote the 
combination of teaching and practice, to carry out a broad variety of Ideological and political education work in the process of students in internship and the professional ethics, professional discipline, professional spirit to infiltrate education, and truly achieve the practice, in the education of education.

2) The combination of education and self-Education. Renowned educator Mr. Ye Shengtao said, "Education is not to teach." In education activities, only when the student teacher Professor feel a heartfelt admiration to the content and put it into self education requirements, such education is successful. Students come to the enterprise internship when not like in school, always has the teacher pour exhortations into sb.'s ear, it needs to be more students self-study, self discipline in practice. Therefore, the ideological and political education of higher business education and self education to carry out the principle of combining, to inspire the students' consciousness of self - education, arouse the enthusiasm of the students self education, guide them through independent study, active participation, self reflection approach developed self education, constantly improve their ideological and moral standards.

3) To solve ideological problems and solving practical problems by combining the ideological and political education is never castles in the air, solving the ideological problems and solving practical problems in combination to enhance actual effect of Ideological and political education. Guangdong University of Foreign Studies professor Peng Weiming wrote one of the reasons why the effectiveness of the ideological and political education is the subject of "the education object need not pay enough attention". Therefore, the ideological and political education of higher business must face up to the specific problems, the students concerned about the hot and difficult issues, should be concerned about their learning, life, facing in the work of the practical difficulties, guide them to correctly face and solve these problems; cultivate their teamwork spirit, strive to use the collective power of solving practical problems. To cultivate the students' learning skills and employability skills combined, the occupation quality education and occupation development ability training together.

\section{B. The Innovation Way}

Under the new situation, higher business professionals to the idea of innovative education, strive to explore to occupation oriented, take the culture of enterprise as the carrier, extension and expansion of the classroom teaching, the new way of Ideological and political education of school and enterprise jointly build, the common implementation.

1) "Clarity the rights and obligations of both parties during the period of school enterprise combination", to form the resultant force of education. In the process of "combining learning with working", how to practice stage to mobilize the initiative and enthusiasm to carry out ideological and political education in enterprises is a problem in the practice of the post. Due to both the University and the enterprise different goals, schools want to assume the responsibility of enterprise ideological and political education in students' post practice process, the corporate culture and business philosophy, management experience and so on as the ideological and political education resources. But the nature of an enterprise is the pursuit of profit, it is difficult to actively undertake to carry out the task of Ideological and political education. Therefore, in order to ensure "talent cultivation of the effective implementation of the model combination" of higher business professional, you should clear the rights and obligations of enterprises in the aspect of Ideological and political education in signed a cooperation agreement with the enterprise. For example, can be in the agreement, the students in enterprise practice process at a fixed time by learning the rules and regulations, exchange experience, teaching experience and other ways of Ideological and political education to the students, and actively guide students self education. At the same time, the school can hire excellent enterprise management personnel as the enterprise ideological and political education instructor, play the "pass, to help with" role, with their work experience and understanding of life to guide students, help them establish a correct goal of life, establish the correct values, improve the effectiveness of ideological and political education.

2) Update the subject of Ideological and political education, realization of the ideological and political education innovation of Ideological and political education idea is essentially a two-way interaction, to jointly improve the process. In the "combination" training mode, because of the ideological and political education environment is complex, the management difficulty is big, higher business professional should further update the subject of Ideological and political education concept, fully aware of subjectivity education in the process of education and the educated is the dialectical unification relations, establishing the subject of ideological and political view of education. In the process of education, to highlight the two-way interaction between teachers and students, establish a good interpersonal relationship in activities and exchanges. To students as the main body of education, to cultivate students moral ability, the idea to improve the quality of education as the goal, to enable them to establish the status of subject in moral life. In addition, the ideological and political education should not only obey the needs of the party and the state, but also should pay attention to students' individual interests. In addition, as far as possible to meet the reasonable demands of the students some of life and learning in the process of education, arouse the learning enthusiasm of students, make students more receptive to the content of Ideological and political education.

3) Integration of enterprise culture, the realization of the contents of Ideological and political education innovation of the enterprise culture is the enterprise in the production, operation, management in the process of creation is the characteristics of the enterprise culture concept, including values, ethics and code of conduct, "the shaping of students' ideology and morality has a positive effect, especially on the formation of students' occupation moral shaping and occupation character, occupation quality has a direct role in. Combination "training mode, higher business professional 
students through the internship experience of corporate culture, so as to obtain the moral experience. Therefore, in the teaching content, the ideological and political education of higher business to adapt teaching content should highlight the occupation, the enterprise culture into the ideological and political education, focus on cultivating the students meet the job requirements of the occupation moral quality. Through the development of campus cultural activities will be the enterprise culture into the campus culture, to the interpretation of corporate culture through invite outstanding entrepreneur of the classroom form, enable the students to establish occupation cognition. To make full use of internship opportunities, to enable students to experience the culture of enterprise, enterprise atmosphere, by osmosis, inner experience and emotion to gradually influence, improve their cognition on enterprises and society, enhance their occupation morals, occupation standard understanding, deepen the student to the target industry, recognized the value of the target enterprise and the target position, realize the dual effect of dominant education and recessive education.

4) The ideological and political education and the practice of mutual infiltration, realize the innovation of Ideological and political education. The ideological and political education of higher business to the classroom education and practice of mutual infiltration, the ideological indoctrination and experience to guide education mode of combining ", enhance the validity period of the ideological and political education work study combination". The ideological and political education of higher business can be combined in various stages of practice, develop and adapt to the educational activities. Before training, led to choose high ideological quality teachers, hiring enterprise relevant personnel as a business mentor. To introduce students to the enterprise and job situation, allowing them to the requirements of the work, discipline, have a preliminary understanding, and carry out the ideological and political education of preventive nature may appear in the practice contents etc.. In the training process, according to the work requirements of duty, labor discipline, according to the enterprise actual situation and the students' time arrangement, to carry out educational activities such as honest and trustworthy, law-abiding, dedication theme in a flexible form of timely. Through conferences, seminars, group discussions, personal feeling way, strengthen the result, timely find and solve problems, make students training in health, harmonious development. At the same time, to "build engineering combined with the special archives" Ideological and political education of the students, the students practice in the enterprise evaluation recorded during performance and related personnel. After the training, to organize the students conscientiously sum up, exchange experience, carry on the positive discussion on "combination" appearing problems during consolidation, "period of Ideological and political education achievements combining engineering".

\section{Conclusion}

At present, the pushing-on talents-training mode of workintegrated learning requires higher expectation in the ideological and political education for commerce specialty in higher vocational colleges. According to the characteristics of talents-training mode of the work-integrated learning and the characteristics of business personnel, the ideological and political education should keep pace with the times to innovate educational ideas in order to explore new approaches of ideological and political education which is guided by profession, carried by enterprise culture. Thus, classroom teaching is extended and expanded; new approaches of ideological and political education are constructed and implemented by college and enterprise.

\section{References}

[1] Liyun Kong, Junzhi Zhao, Tinghua Li. Discussion on difficulties and new approaches of moral education for college students majoring in performance art. Proceedings of 2014 International Conference on Economic Management and Social Science. 2014

[2] Xuelian Chen. Analysis of Ideological and Political Education and Teaching Modes Based on Philosophical Theoretical View. Proceedings of International Conference on Education Technology and Social Science. 2014

[3] Wu Xiaolin. Discussion on the Social education of contemporary college students' socialist core values. Proceedings of 2014 2nd International Conference on Education Technology and Information System. 2014

[4] Chao Kang. Analysis of Ideological and Political Education Model in Colleges from the Perspective of Overall Process. Proceedings of 2014 2nd International Conference on Education Technology and Information System. 2014.

[5] Aizhen Lv,Jingbin Wang. Investigation of public integrity education of contemporary college students-Case study of some colleges in Jinan. Proceedings of 2014 2nd International Conference on Education Technology and Information System. 2014 